\title{
Bone biopsy in nephrology practice
}

\author{
Biópsia óssea na prática nefrológica
}

\section{Authors \\ Fellype de Carvalho Barreto ${ }^{1}$ Cleber Rafael Vieira da Costa ${ }^{2}$ Luciene Machado dos Reis ${ }^{3}$ Melani Ribeiro Custódio ${ }^{3}$}

${ }^{1}$ Universidade Federal do Paraná, Divisão de Nefrologia, Curitiba, PR, Brasil.

${ }^{2}$ Fundação Pro-Renal , Curitiba, PR, Brasil.

${ }^{3}$ Universidade de São Paulo, Faculdade de Medicina, Hospital das Clinicas, Laboratório de Fisiopatologia Renal São Paulo, SP, Brasil.

Submitted on: 12/05/2017. Approved on: 07/09/2018.

\section{Correspondence to:}

Melani Ribeiro Custódio.

E-mail: melrcustodio@yahoo.com.br

DOI: 10.1590/2175-8239-JBN-2017-0012

\section{Abstract}

Renal osteodystrophy (ROD), a group of metabolic bone diseases secondary to chronic kidney disease (CKD), still represents a great challenge to nephrologists. Its management is tailored by the type of bone lesion - of high or low turnover - that cannot be accurately predicted by serum biomarkers of bone remodeling available in daily clinical practice, mainly parathyroid hormone (PTH) and alkaline phosphatase (AP). In view of this limitation, bone biopsy followed by bone quantitative histomorphometry, the gold-standard method for the diagnosis of ROD, is still considered of paramount importance. Bone biopsy has also been recommended for evaluation of osteoporosis in the CKD setting to help physicians choose the best anti-osteoporotic drug. Importantly, bone biopsy is the sole diagnostic method capable of providing dynamic information on bone metabolism. Trabecular and cortical bones may be analyzed separately by evaluating their structural and dynamic parameters, thickness and porosity, respectively. Deposition of metals, such as aluminum and iron, on bone may also be detected. Despite of these unique characteristics, the interest on bone biopsy has declined over the last years and there are currently few centers around the world specialized on bone histomorphometry. In this review, we will discuss the bone biopsy technique, its indications, and the main information it can provide. The interest on bone biopsy should be renewed and nephrologists should be capacitated to perform it as part of their training during medical residency.

Keywords: Biopsy; Bone and Bones; Histology; Bone Histomorphometry; Chronic Kidney Disease-Mineral and Bone Disorder; Renal Insufficiency, Chronic.

\section{Resumo}

A osteodistrofia renal (OR), um grupo de doenças ósseas metabólicas secundárias à doença renal crônica (DRC), ainda representa um grande desafio para os nefrologistas. Seu manejo é individualizado de acordo com o tipo de lesão óssea - de alto ou baixo remodelamento - cujo diagnóstico não pode ser prevista com precisão pelos biomarcadores séricos de remodelação óssea disponíveis na prática clínica diária, principalmente o paratormônio (PTH) e a fosfatase alcalina (FA). Em vista dessa limitação, biópsia óssea seguida de histomorfometria óssea quantitativa, método padrão-ouro para o diagnóstico de OR, ainda é considerado um procedimento de grande importância. A biópsia óssea também é recomendada na avaliação da osteoporose em indivíduos com DRC, a fim de auxiliar na escolha do melhor medicamento anti-osteoporótico. É importante observar que a biópsia óssea é o único método diagnóstico capaz de proporcionar informações dinâmicas sobre o metabolismo ósseo. Os ossos trabecular e cortical podem ser analisados separadamente por meio da avaliação de seus parâmetros estruturais e dinâmicos, espessura e porosidade, respectivamente. A deposição óssea de metais como alumínio e ferro também pode ser detectada. Apesar de suas características singulares, o interesse pela biópsia óssea diminuiu nos últimos anos. Poucos centros em todo o mundo são especializados em histomorfometria óssea. A presente revisão discute a técnica de biópsia óssea, suas indicações e as principais informações que ela pode oferecer. $\mathrm{O}$ interesse pela biópsia óssea deve ser renovado e os nefrologistas devem ser capacitados a realizá-la durante o período de residência médica.

Palavras-chave: Biópsia; Osso e Ossos; Histologia; Histomorfometria Óssea; Distúrbio Mineral e Ósseo da Doença Renal Crônica; Insuficiência Renal Crônica. 


\section{INTRODUCTION}

Abnormalities in circulating parameters of mineral and bone metabolism may appear early in the course of chronic kidney disease and they have been associated to increased mortality and morbidity, and decreased quality of life. ${ }^{1,2}$ In 2006, the term chronic kidney disease-mineral and bone disorders (CKD-MBD) was implemented by the Kidney Disease Improving Global Outcomes (KDIGO) working group ${ }^{3}$ to refer to the systemic disorder of mineral and bone metabolism due to CKD; it is manifested by either one or a combination of: 1) abnormalities of calcium (Ca), phosphorous (P), PTH and vitamin D metabolism; 2) abnormalities of bone turnover, mineralization, volume (TMV), linear growth or strength; and 3) vascular or other soft tissue calcification. There are many studies showing that these disorders are related to adverse clinical outcomes, in particular cardiovascular disease, fractures, and mortality, reaffirming the importance of this systemic pathological process. ${ }^{4-7}$

In 2009, KDIGO published clinical guidelines for the diagnosis, prevention, and treatment of CKDMBD. Renal osteodystrophy (ROD), a group of metabolic bone diseases that occurs through the evolution of CKD, is part of the manifestations of CKD-MBD. The term 'renal osteodystrophy' has been limited to the histologic analysis of bone lesions, requiring the use of bone biopsy. ${ }^{8,9}$

Bone biopsy is considered the gold-standard method for histological classification of ROD. ${ }^{3,8-10}$ It is performed in the iliac crest, after double tetracycline labeling, allowing that the different histological alterations of bone tissue that make up the ROD spectrum can be diagnosed and classified by quantitative histomorphometry. This analysis consists on the evaluation of structural and dynamic parameters, such as trabecular bone volume, bone cell numbers, bone formation, and mineralization. ROD may be classified according to TMV criteria into one of the following patterns: (i) low-turnover bone disease, which includes adynamic bone disease (ABD) and osteomalacia $(\mathrm{OM})$; or (ii) high-turnover bone disease, which encompasses bone disease related to secondary hyperparathyroidism (SHPT), or osteitis fibrosa, and mixed uremic osteodystrophy (MUO)., ${ }^{3,11,12}$ Figure 1 shows the different types of ROD and their characteristics. High-turnover bone disease are exemplified in figures $1 \mathrm{~A}, 1 \mathrm{~B}, 1 \mathrm{C}$, and $1 \mathrm{D}$, and low-turnover bone disease in figures $1 \mathrm{E}, 1 \mathrm{~F}, 1 \mathrm{G}$, and $1 \mathrm{H}$.
Another important analysis is the thickness and porosity of cortical bone. About $80 \%$ of all fractures occurs at non-vertebral sites, at regions comprising large amounts of cortical bone. In the past, trabecular bone and vertebral fractures had been the hallmarks of osteoporotic fractures, but recently the role of cortical bone in bone fragility has gained a growing interest. ${ }^{5,13}$ In the general population, cortical lesions have been consistently associated with increased fracture risk, as is observed in post-menopausal women. Bjornerem $e$ t $a l^{14}$ in a high-resolution peripheral CT study, showed that cortical porosity and thickness are the main factors determining the bone fragility that underlies non-vertebral fracture risk.

CKD is associated with higher risk of fractures, being $4 \mathrm{x}$ greater in these patients than in the general population, increasing mortality significantly. ${ }^{15-17}$ One possible explanation is that in CKD there is a decrease in bone mass with impaired bone strength and a high risk of fall, predisposing to fractures. ${ }^{18}$ Taking these data into account, information obtained through quantitative histomorphometric analysis of bone tissue may be help us to understand the mechanisms behind the assoication of bone abnormalities and clinical outcomes, which may be crucial to improve the manangement of bone disease. ${ }^{9,19}$ Table 1 shows characteristics of ROD according to histomorphometric parameters. Osteoporosis might be present in any type of bone disease, with the exception of osteomalacia.

Bone biopsy is an invasive and costly procedure that requires specialized centers for histomorphometric analysis. Therefore, it has not been recommended as part of the routine evaluation of CKDMBD. ${ }^{9,13}$ The biomarkers of bone remodeling PTH and AP, both total and the fraction, have been considered a helpful tool for predicting ROD type. ${ }^{8,20}$ Otherwise, some studies have reported that PTH is a poor biomarker of bone disease due to its high biological variability. ${ }^{20,21}$ In dialysis patients, PTH levels $<100$ and $>450 \mathrm{pg} / \mathrm{mL}$ have been associated with low- and high-turnover bone disease, respectively, The predictive value of PTH is not considered ideal especially when its level is between $150-450 \mathrm{pg} /$ $\mathrm{mL}$, a gray zone where any type of bone histology may occur, including normal bone. ${ }^{22}$ Serum AP is a marker of bone formation. In general, its variation parallels that of $\mathrm{PTH}$, providing additional information for predicting the type of ROD. ${ }^{23,24}$ In some 
Figure 1. Representative photomicrographs of under-calcified bone showing different types of renal osteodystrophy. MB: mineralized bone; BM: bone marrow. A) Histological characteristics of osteitis fibrosa, showing an increased bone formation represented by osteoid surface (O), osteoblast number (Obl), resorption, and osteoclast number (Ocl). There is an extensive area of marrow fibrosis (MF). Toluidine Blue (x100). B) Fluorescent double-labels (DL) observed in osteitis fibrosa. Unstained bone section under ultraviolet (UV) light (x125). C) Histological characteristics observed in mixed uremic osteodystrophy, represented by an increased bone formation, showing osteoid surface (O), osteoblast number (Obl), resorption and osteoclast number $(\mathrm{Ocl})$, and an extensive area covered by marrow fibrosis (MF). Toluidine blue (x100). D) The major difference between mixed uremic osteodystrophy and osteitis fibrosa is the impaired mineralization observed in this type of disease, as a consequence of the increased confluent labels not observed in osteitis fibrosa. Unstained bone section under UV light (x125). E) Histological characteristics of Osteomalacia, showing a dramatic increase of bone formation represented by an extensive osteoid surface (O) and thickness (arrow). Toluidine blue ( $\mathrm{x} 100)$. F) Confluent fluorescent labels (CL) observed in osteomalacia. Unstained bone section under UV light (x250). G) Histological characteristics observed in adynamic bone disease, showing decreased bone formation and resorption and no marrow fibrosis (MF). Toluidine blue ( $x 40$ ). H) Fluorescent labels in adynamic bone disease can be scarce, representing a decreased mineralization as observed in this unstained bone section under UV light (x50).

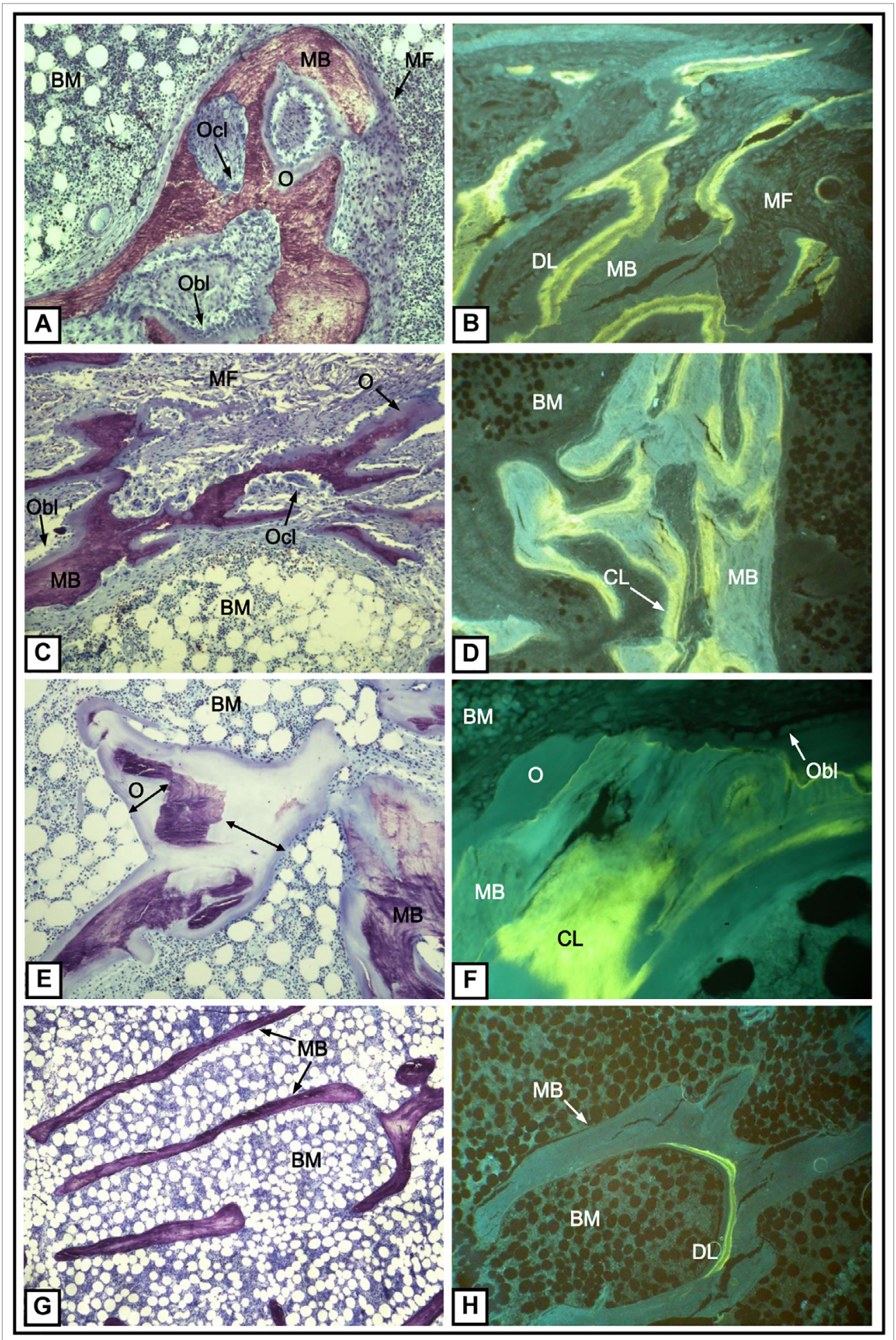




\begin{tabular}{|c|c|c|c|c|}
\hline Histomorphometric parameters & Osteitis Fibrosa & $\begin{array}{l}\text { Mixed bone } \\
\text { disease }\end{array}$ & $\begin{array}{c}\text { Adynamic bone } \\
\text { disease }\end{array}$ & Osteomalacia \\
\hline \multicolumn{5}{|l|}{ Structural } \\
\hline BV/TV (\%) & Normal/low & Normal/low & Normal/low & Normal/increased \\
\hline Tb.Sp $(\mu \mathrm{m})$ & Normal/increased & Normal/increased & Normal/increased & Normal/decreased \\
\hline Tb.Th $(\mu \mathrm{m})$ & Normal/decreased & Normal/decreased & Normal/decreased & increased \\
\hline Tb.N (/mm) & Normal/decreased & Normal/decreased & Normal/decreased & Normal/increased \\
\hline \multicolumn{5}{|l|}{ formation } \\
\hline OV/BV (\%) & increased & increased & Normal & increased \\
\hline OS/BS (\%) & Normal/increased & Normal/increased & Normal & increased \\
\hline O.Th $(\mu \mathrm{m})$ & Normal/increased & Normal/increased & Normal & increased \\
\hline Ob.S/BS (\%) & increased & increased & Normal/decreased & Normal/ decreased \\
\hline \multicolumn{5}{|l|}{ resorption } \\
\hline ES/BS (\%) & Normal/increased & increased & Normal/increased & Normal \\
\hline Oc.S/BS (\%) & increased & increased & Normal/increased & Normal/decreased \\
\hline \multicolumn{5}{|l|}{ mineralization } \\
\hline MS/BS (\%) & Normal & decreased/absent & Normal/decreased & decreased \\
\hline $\operatorname{MAR}(\mu \mathrm{m})$ & Normal & Normal/increased & Normal/decreased & decreased \\
\hline BFR/BS $\left(\mu m^{3} / \mu m^{2} /\right.$ day $)$ & increased & increased & decreased & decreased \\
\hline Mlt (days) & Normal/increased & increased & normal/increased & increased \\
\hline \multicolumn{5}{|l|}{ Bone and marrow fibrosis } \\
\hline $\mathrm{Fb} . \mathrm{V} / \mathrm{TV}(\%)$ & yes* & yes* & yes**/no & no \\
\hline
\end{tabular}

BV/TV: bone volume; Tb.Sp: trabecular separation; Tb.Th: trabecular thickness; Tb.N: trabecular number; OV/BV: osteoid volume; OS/BS: osteoid surface; O.Th: osteoid thickness; Ob.S/BS: osteoblastic surface; ES/BS: resorption surface; Oc.S/BS: osteoclastic surface; MS/ BS: mineralizing surface; MAR: mineral aposition rate; BFR/BS: bone formation rate; Mlt: mineralization lag time; Fb.V/TV: fibrosis volume, * higher than $0.5 \%$ and ${ }^{*}$ lower than $0.5 \%$;

circumstances, the values of these markers may be divergent, such as high PTH and low total AP levels, which suggests the presence of SHPT associated with a low-turnover bone disease. This apparent paradox can be secondary to aluminum intoxication or over suppression of bone remodeling by active vitamin $\mathrm{D}$ therapy. Bone biopsy may be fundamental for clarifying this blurred scenario. ${ }^{25}$

It is worth mentioning that bone biopsy may also provide a complementary view of bone tissue alterations, such as the detection of aluminum and/or iron intoxication and the presence of low bone volume, a finding suggestive of osteoporosis. ${ }^{26,27}$ Bone biopsy can also provide bone tissue sample for immunohistochemical analysis, molecular studies, data on efficacy and safety of different drugs, among other advantages; ${ }^{28-31}$ its main indications are listed in Table 2.

Finally, in view of the limitations of the serum biomarkers, other diagnostic methods have been used for the analysis of bone diseases. ${ }^{32}$ Dual energy X-ray absorptiometry (DXA), ${ }^{33}$ quantitative computerized tomography (QCT), ${ }^{34}$ high resolution-peripheral QCT (HR-pQCT) ${ }^{35}$ and micro magnetic resonance imaging (MRI) ${ }^{36}$ are imaging methods that quantify bone mass and structural aspects of bone quality. Importantly, they do not measure neither and mineralization nor determine ROD type. Thus, currently the non-invasive assessment of bone turnover and mineralization is still suboptimal. ${ }^{20,37}$ Table 3 depicts the advantages and limitations of different methods of bone tissue evaluation.

The update of KDIGO guidelines for CKD-MBD, ${ }^{8}$ in addition to reinforcing all classical indications, calls attention to the importance of bone biopsy to guide treatment in CKD 3a-5D patients with low BMD, and high risk of osteoporosis.

According to a recent survey conducted among European nephrologists, bone biopsies are performed rather exceptionally, both for clinical and research purposes. Many difficulties were identified, especially 


\section{TABLE 2 INDICATIONS OF BONE BIOPSY IN CKD PATIENTS}

1. Persistent bone pain;

2. Unexplained hypercalcemia and/or hypophosphatemia;

3. Fragility fracture;

4. Discrepancy between serum biomarkers and clinical presentation;

5. Suspicion of aluminum and/or iron intoxication;

6. Before using anti-osteoporotic drugs, such as bisphosphonates and denosumab.

Table 3 Advantages and limitations of Different Methods fOR the EVALUATION Of BONE tISSUE

\begin{tabular}{|c|c|c|}
\hline & Advantages & Limitations \\
\hline \multirow{4}{*}{ Serum biomarkers of bone remodelling } & Low cost & \multirow{2}{*}{$\begin{array}{l}\text { Kidney function may interfere on } \\
\text { levels }\end{array}$} \\
\hline & Availability & \\
\hline & Non-invasive & $\begin{array}{l}\text { Low to moderate accuracy to predict } \\
\text { the type of ROD }\end{array}$ \\
\hline & $\begin{array}{l}\text { Provide guidance for the treatment of CKD-MBD } \\
\text { in the daily clinical practice }\end{array}$ & Lack of information on bone density \\
\hline \multirow{4}{*}{ DXA } & Non-invasive & \multirow{2}{*}{$\begin{array}{l}\text { Lack of differentiation between } \\
\text { cortical and trabecular bone }\end{array}$} \\
\hline & Low cost & \\
\hline & Availability & \multirow{2}{*}{$\begin{array}{l}\text { Lack of information on bone } \\
\text { mineralization, turnover and } \\
\text { microarchitecture }\end{array}$} \\
\hline & Prediction of bone fracture & \\
\hline \multirow{6}{*}{ HR-qCT } & Non-invasive & $\begin{array}{l}\text { High cost, radiation exposure, low } \\
\text { availability }\end{array}$ \\
\hline & High definition image & Limited to peripheral sites \\
\hline & Assesses separately cortical and trabecular bone & \multirow{4}{*}{$\begin{array}{l}\text { Lack of information on bone } \\
\text { mineralization and turnover } \\
\text { Lack of standardization } \\
\text { Few studies in CKD patients }\end{array}$} \\
\hline & Assesses bone density and microarchitecture. & \\
\hline & Estimation of bone strength & \\
\hline & & \\
\hline \multirow{5}{*}{$\mathrm{MRI}$} & Non-invasive, no radiation & \multirow{2}{*}{$\begin{array}{l}\text { High cost } \\
\text { Low availability }\end{array}$} \\
\hline & Assesses separately cortical and trabecular bone & \\
\hline & Can produce 3D images & \multirow{2}{*}{$\begin{array}{l}\text { Lack of information on bone } \\
\text { mineralization and turnover }\end{array}$} \\
\hline & Shows other aspects of bone physiology not & \\
\hline & $\begin{array}{l}\text { assessed by other techniques, such as marrow } \\
\text { fat content, perfusion and molecular diffusion }\end{array}$ & Few studies in CKD patients \\
\hline \multirow{5}{*}{ Bone biopsy + histomorphometry } & Hiah snecificity and sensibility to diaanose bone & Invasive, painful, cost \\
\hline & diseases, including ROD & \multirow{2}{*}{$\begin{array}{l}\text { Few specialized centres on this } \\
\text { technique }\end{array}$} \\
\hline & Assesses separately cortical and trabecular bone & \\
\hline & Information on bone mineralization and turnover & \multirow{2}{*}{$\begin{array}{l}\text { Does not evaluate bone density } \\
\text { No data on fracture risk prediction }\end{array}$} \\
\hline & & \\
\hline
\end{tabular}
Abbreviations: DXA: dual X-ray absorptiometry; HR-qCT, high resolution - quantitative peripheral computerized tomography; MRI, magnetic resonance image.

the costly histopathological analysis, lack of histopathological expertise, and no established reimbursement in several countries. ${ }^{10}$

In March 2016, the European Renal Osteodystrophy (EU-ROD) initiative was created to revitalize bone biopsy as a clinically useful tool in the diagnosis of CKDMBD to improve outcomes in CKD patients. ${ }^{10}$ In Brazil, Oliveira RB et al created the Brazilian Registry of Bone Biopsy (REBRABO), a national registry that serves as a research platform to expand the knowledge about CKD-MBD. ${ }^{38}$
In the next sections of article, we will overview the protocol of tetracycline labeling, and the technique to perform bone biopsy, its indications and complications. Finally, the main information provided by bone histomorphometric analysis will be discussed.

\section{DOUBLE TETRACYCLINE LABELING}

Patients should take tetracycline previously to the bone biopsy for an adequate evaluation of the type of bone disease. Tetracycline, a macrolide antibiotic, deposits on bone surface allowing the assessment of 
dynamic parameters of bone formation and mineralization. The tetracycline administration scheme we have been using in our services is the following: first course of tetracycline for 3 days, $500 \mathrm{mg}$ twice a day; a tetracycline-free interval of 10 days; a second course of tetracycline for 3 days, $500 \mathrm{mg}$ twice a day. Bone biopsy must be performed from 3 to 5 days after the end of the second course of tetracycline. ${ }^{9-11}$

\section{BONE BIOPSY MATERIAL}

The material required for performing bone biopsy is (i) a minor surgery pack containing 1 Kelly thin straight tweezer, 1 rat tooth tweezer, 1 small bowl, 1 medium straight scissor, 1 needle holder, 1 syringe (20 $\mathrm{mL}$ ); 1 suture thread (3.0); 1 bistoury blade; (ii) 1 set of trephine needle for bone biopsy; and (iii) 1 electric drill. Figure 2 illustrates these materials.

\section{TRANSILIAC BONE BIOPSY PROCEDURE}

Transiliac bone biopsy can be performed in an ambulatory surgical center in most cases. Mild sedation with midazolam, administered by intravenous or intramuscular route, should be used. Performing bone biopsy in obese patients and in children may require in-hospital surgical center and the presence of anesthesiologist.
The first step of bone biopsy procedure is to define the correct site on the iliac crest. The superior iliac crest should be located and imaginary lines drawn 2 $\mathrm{cm}$ below and $2 \mathrm{~cm}$ inwards toward the contralateral shoulder, forming a $90^{\circ}$ angle with the iliac bone.

Asepsis should be made before starting the procedure with, for example, alcoholic chlorhexidine. For local anesthesia, a button on the skin of around $2 \mathrm{~cm}$ should be made in the incision site. The anesthetic should be injected along the biopsy path and into the periosteum of the external cortical. The internal cortical bone may also be anesthetized by entering with a needle $2 \mathrm{~cm}$ below and posterior to the iliac crest. In the previously defined point, a $2 \mathrm{~cm}$ incision should be made. Thereafter, the muscle plans should be gently divulged to avoid bleeding, using a straight Kelly to make a tunnel from the skin until the periosteum. Once the tunnel is made, the Rochester Bone Biopsy kit that includes a pointed obturator (number 87410), a guide sleeve (number 87420), a drive adaptor (number 87450), a Trephine cutter (number 87401) and a blunt extractor (number 87440) (Figure 2) will be used for the following steps:

1- The pointed obturator should be inserted through the incision until reaching the surface of the ilium to further localize the biopsy site.

Figure 2. Bone biopsy materials.

A-Trephine: Rochester Bone Biopsy Trephine (www.medicalinnovations.com) pointed obturator (number 87410), guide sleeve (number 87420), drive adaptor (number 87450), trephine needle (number 87401), and blunt extractor (number 87440)

B- Electric drill: DeWALT ${ }^{\circledR}$, wireless, 1.2 kg, 12 V Lithium Battery Bivolt Dcd700l

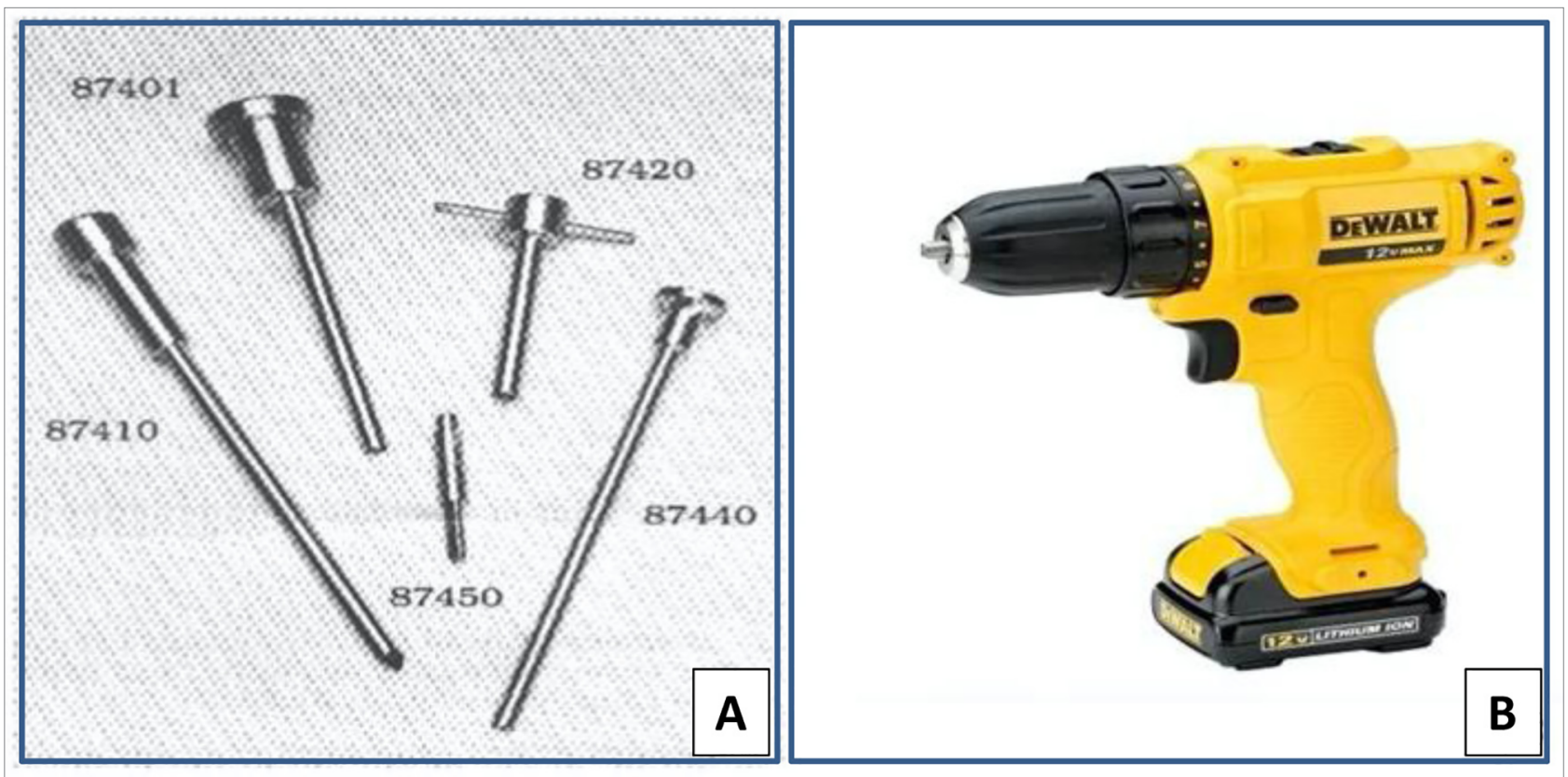


2- The pointed obturator should be removed and connected to the guide sleeve. The assembly should be reintroduced into the tunnel until the previously determined site of biopsy. The guide sleeve should be held firmly while the pointed obturator is withdrawn.

3- The Trephine needle should be connected to the drive adaptor and coupled to the drill, being firmly fastened to the drill.

4- The assembly should be inserted into the guide sleeve, which acts as a catch lock. the Trephine must not exceed the guide sleeve more than 3 $\mathrm{cm}$ to assure that it will not excessively overpass the ilium.

5- The drill should be driven forward rotating in the clockwise direction. The Trephine needle should pass through the external cortical, trabecular, and internal cortical bone, to obtain an adequate bone sample. Thereafter, the direction of the drill rotation should be set to counterclockwise and the drill driven backwards.

6- The bone fragment should be removed from the trephine needle using the blunt extractor.

7- The incision wound should be compressed for 5 minutes to stop bleeding.

8- The incision should be cleaned and sutured using Donati technique.

9- A compressive dressing should be made to prevent bleeding.

The bone fragment size should be variable, depending on factors such as gender and patient size. It is considered adequate when the fragment is composed of two cortical (internal and external) bones at the extremities and trabecular bone in the middle. Importantly, the bone specimen should not be fractured during the procedure. The sample should be stored in a vial containing $70 \%$ alcohol and protected from light exposure. Formalin should not be used because it may damage the bone tissue.

\section{COMPLICATIONS OF BONE BIOPSY}

The transiliac bone biopsy has been proved to be safe and associated with minor complications, which incidence is of $0.63 \% .^{39,40}$ The most common complications are bleeding, hematoma, infection, superficial nerve injury, and pain. Routine prophylactic antibiotic administration is not recommended. Antibiotics should be reserved for the cases of excessive manipulation or accidental contamination. The main recommendations for patient after bone biopsy are listed in Table 4 .

\section{HISTOMORPHOMETRIC ANALYSIS}

The bone biopsy result is reported according to the TMV classification. Briefly, it indicates if bone turnover $(\mathrm{T})$ and volume $(\mathrm{V})$ are low, normal, or increased, and if the mineralization (M) is normal or abnormal. The high-turnover bone diseases comprise SHPT-related bone disease (Figure 1A and 1B) or MUO (Figure 1C). Both are characterized by an increase in the number and activity of bone cells (osteoblasts and osteoclasts) and, consequently, higher bone formation and resorption. (Table 1) The presence of bone marrow fibrosis is a common finding in high-turnover state (Table 1). The main difference between these two patterns of high-turnover bone disease is the presence of abnormal mineralization in MUO (Figure $1 \mathrm{D}$; Table 1). Bone volume may be decreased in any type of ROD (excepted osteomalacia), indicating a predominance of bone resorption over bone formation (Table 1) and greater brittleness of bone tissue. Low-bone turnover disease is characterized by low cellularity (reduced number of osteoclasts and osteoclasts). Low bone formation and mineralization (Figure $1 \mathrm{G}$ and $1 \mathrm{H}$; Table 1 ) are the main finding of $\mathrm{ABD}$ while a greater impairment of bone mineralization, leading to the accumulation of the osteoid matrix, is the main finding of osteomalacia (Figure 1F; Table1). Finally, it should be

Table 4 Patient ReCommendations After bone Biopsy PROCEDURE

- The patient must take a day off

- The patient should not perform heavy tasks for the following 3 days.

- The dressing should be removed 24 hours after the procedure.

- The surgical wound can be washed with soap and water.

- A new dressing or a Band-Aid may be used.

- Painkillers, such as dipyrone or paracetamol, for alleviating pain.

- Heparin should be avoided during the hemodialysis session following the bone biopsy.

- The stitches should be removed 7 - 10 days after the procedure. 
mentioned that despite being commonly performed in trabecular bone, the histomorphometric analysis may also be used to evaluate the cortical bone. Cortical thickness and porosity may be assessed by this method. Lower thickness and greater porosity of the cortical bone indicate greater fragility and, therefore, greater risk of fracture. The presence of aluminum deposits can be evaluated by Solochrome Azurine and iron by Perls' Prussian Blue staining.

\section{Centers for BONE histomorPHOMETRY ANALYSIS IN BRAZIL}

Currently, there are four centers specialized on bone histomorphometry in Brazil, three located in São Paulo and one in Paraná. They are:

1- Laboratório de Fisiopatologia Renal - Lim 16 - Faculdade de Medicina da Universidade de São Paulo (FMUSP).

2- Laboratório de Osteodistrofia Renal - Disciplina de Nefrologia - Universidade Federal de São Paulo (UNIFESP).

3- Laboratório PRO, Fundação Pró-Renal Brasil - Curitiba.

4- Laboratório para Estudo do Distúrbio Mineral e Ósseo em Nefrologia (LEMON) - disciplina de Nefrologia - Universidade de Campinas (UNICAMP).

\section{Conclusion}

Bone biopsy is an important procedure that provides helpful information on bone microarchitecture, turnover and, ultimately, on the type of ROD. This information may be critical for choosing the most appropriate therapy for CKD-MBD and other findings as osteoporosis, aluminum and/or iron intoxication. Nephrologists should be capacitated to perform bone biopsy as part of their training during medical residency.

\section{References}

1. Block GA, Klassen PS, Lazarus JM, Ofsthun N, Lowrie EG, Chertow GM. Mineral metabolism, mortality, and morbidity in maintenance hemodialysis. J Am Soc Nephrol 2004;15:2208-18.

2. Go AS, Chertow GM, Fan D, McCulloch CE, Hsu CY. Chronic kidney disease and the risks of death, cardiovascular events, and hospitalization. New Eng J Med 2004;351:1296-305.

3. Moe S, Drüeke T, Cunningham J, Goodman W, Martin K, Olgaard $\mathrm{K}$, et al.; Kidney Disease: Improving Global Outcomes (KDIGO). Definition, evaluation, and classification of renal osteodystrophy: a position statement from Kidney Disease: Improving Global Outcomes (KDIGO). Kidney Int 2006;69:1945-53.
4. Nickolas TL, McMahon DJ, Shane E. Relationship between moderate to severe kidney disease and hip fracture in the United States. J Am Soc Nephrol 2006;17:3223-32.

5. Ball AM, Gillen DL, Sherrard D, Weiss NS, Emerson SS, Seliger SL, et al. Risk of hip fracture among dialysis and renal transplant recipients. JAMA 2002;288:3014-8.

6. Dooley AC, Weiss NS, Kestenbaum B. Increased risk of hip fracture among men with CKD. Am J Kidney Dis 2008;51:3844.

7. Cozzolino M, Urena-Torres P, Vervloet MG, Brandenburg V, Bover J, Goldsmith D, et al.; CKD-MBD Working Group of ERA-EDTA. Is chronic kidney disease-mineral bone disorder (CKD-MBD) really a syndrome? Nephrol Dial Transplant 2014;29:1815-20.

8. Ketteler M, Block GA, Evenepoel P, Fukagawa M, Herzog CA, McCann L, et al. Executive summary of the 2017 KDIGO Chronic Kidney Disease-Mineral and Bone Disorder (CKD-MBD) Guideline Update: what's changed and why it matters. Kidney Int 2017;92:26-36.

9. Kidney Disease: Improving Global Outcomes CKDMBD Work Group. KDIGO clinical practice guideline for the diagnosis, evaluation, prevention, and treatment of Chronic Kidney Disease-Mineral and Bone Disorder (CKD-MBD). Kidney Int Suppl 2009;(113):S1-130.

10. Evenepoel P, Behets GJS, Laurent MR, D'Haese PC. Update on the role of bone biopsy in the management of patients with CKD-MBD. J Nephrol 2017;30:645-52.

11. Ott SM. Histomorphometric measurements of bone turnover, mineralization, and volume. Clin J Am Soc Nephrol 2008;3 Suppl 3:S151-6.

12. Malluche HH, Mawad HW, Monier-Faugere MC. Renal osteodystrophy in the first decade of the new millennium: analysis of 630 bone biopsies in black and white patients. J Bone Miner Res 2011;26:1368-76.

13. Carvalho C, Alves CM, Frazão JM. The role of bone biopsy for the diagnosis of renal osteodystrophy: a short overview and future perspectives. J Nephrol 2016;29:617-26.

14. Biørnerem Å, Bui QM, Ghasem-Zadeh A, Hopper JL, Zebaze R, Seeman E. Fracture risk and height: an association partly accounted for by cortical porosity of relatively thinner cortices. J Bone Miner Res 2013;28:2017-26.

15. Alem AM, Sherrard DJ, Gillen DL, Weiss NS, Beresford SA, Heckbert SR, et al. Increased risk of hip fracture among patients with end-stage renal disease. Kidney Int 2000;58:396-9.

16. Jadoul M, Albert JM, Akiba T, Akizawa T, Arab L, Bragg-Gresham JL, et al. Incidence and risk factors for hip or other bone fractures among hemodialysis patients in the Dialysis $\mathrm{Ou}$ tcomes and Practice Patterns Study. Kidney Int 2006;70:135866.

17. Tentori F, McCullough K, Kilpatrick RD, Bradbury BD, Robinson BM, Kerr PG, et al. High rates of death and hospitalization follow bone fracture among hemodialysis patients. Kidney Int 2014;85:166-73.

18. Naylor KL, McArthur E, Leslie WD, Fraser LA, Jamal SA, Cadarette SM, et al. The three-year incidence of fracture in chronic kidney disease. Kidney Int 2014;86:810-8.

19. Steller Wagner Martins C, Jorgetti V, Moysés RMA. Time to rethink the use of bone biopsy to prevent fractures in patients with chronic kidney disease. Current Opin Nephrol Hyperten 2018;27:243-50.

20. Sprague SM, Bellorin-Font E, Jorgetti V, Carvalho AB, Malluche HH, Ferreira A, et al. Diagnostic Accuracy of Bone Turnover Markers and Bone Histology in Patients With CKD Treated by Dialysis. Am J Kidney Dis 2016;67:559-66.

21. Evenepoel P, Bover J, Ureña Torres P. Parathyroid hormone metabolism and signaling in health and chronic kidney disease. Kidney Int 2016;90:1184-90.

22. Barreto FC, Barreto DV, Moyses RM, Neves KR, Canziani ME, Draibe SA, et al. K/DOQI-recommended intact PTH levels do not prevent low-turnover bone disease in hemodialysis patients. Kidney Int 2008;73:771-7. 
23. Bergman A, Qureshi AR, Haarhaus M, Lindholm B, Barany P, Heimburger $\mathrm{O}$, et al. Total and bone-specific alkaline phosphatase are associated with bone mineral density over time in end-stage renal disease patients starting dialysis. J Nephrol 2017;30:255-62.

24. Bover J, Ureña P, Aguilar A, Mazzaferro S, Benito S, López-Báez V, et al. Alkaline Phosphatases in the Complex Chronic Kidney Disease-Mineral and Bone Disorders. Calcif Tissue Int 2018;103:111-24.

25 . Chiang $\mathrm{C}$. The use of bone turnover markers in chronic kidney disease-mineral and bone disorders. Nephrology (Carlton) 2017;22:11-3.

26. Malluche HH. Aluminium and bone disease in chronic renal failure. Nephrol Dial Transplant 2002;17:21-4.

27. Rocha LA, Barreto DV, Barreto FC, Dias CB, Moysés R, Silva $M R$, et al. Serum ferritin level remains a reliable marker of bone marrow iron stores evaluated by histomorphometry in hemodialysis patients. Clin J Am Soc Nephrol 2009;4:105-9.

28. Behets GJ, Spasovski G, Sterling LR, Goodman WG, Spiegel DM, De Broe ME, et al. Bone histomorphometry before and after long-term treatment with cinacalcet in dialysis patients with secondary hyperparathyroidism. Kidney Int 2015;87:846-56.

29. Santos MFP, Hernandez MJ, de Oliveira IB, Siqueira FR, Dominguez WV, Dos Reis LM, et al. Comparison of clinical, biochemical and histomorphometric analysis of bone biopsies in dialysis patients with and without fractures. J Bone Miner Metab 2018 Jan 25. DOI: 10.1007/s00774-018-0902-7. [Epub ahead of print]

30. Graciolli FG, Neves KR, Barreto F, Barreto DV, Dos Reis LM, Canziani ME, et al. The complexity of chronic kidney disease-mineral and bone disorder across stages of chronic kidney disease. Kidney Int 2017;91:1436-46.
31. Malluche HH, Mawad H, Monier-Faugere MC. Effects of treatment of renal osteodystrophy on bone histology. Clin J Am Soc Nephrol 2008;3:S157-63.

32. Malluche HH, Porter DS, Pienkowski D. Evaluating bone quality in patients with chronic kidney disease. Nat Rev Nephrol 2013;9:671-80.

33. Sabin MA, Blake GM, MacLaughlin-Black SM, Fogelman I. The accuracy of volumetric bone density measurements in dual x-ray absorptiometry. Calcif Tissue Int 1995;56:210-4.

34. Dall'Ara E, Pahr D, Varga P, Kainberger F, Zysset P. QCT-based finite element models predict human vertebral strength in vitro significantly better than simulated DEXA. Osteoporos Int 2012;23:563-72.

35. Nishiyama KK, Shane E. Clinical imaging of bone microarchitecture with HR-pQCT. Curr Osteoporos Rep 2013;11:147-55.

36. Wehrli FW. Structural and functional assessment of trabecular and cortical bone by micro magnetic resonance imaging. J Magn Reson Imaging 2007;25:390-409.

37. Torres PAU, Cohen-Solal M. Evaluation of fracture risk in chronic kidney disease. J Nephrol 2017;30:653-61.

38. de Oliveira RB, Barreto FC, Custódio MR, Gueiros JE, Neves CL, Karohl C, et al. Brazilian Registry of Bone Biopsy (REBRABO): design, data elements and methodology. J Bras Nefrol 2014;36:352-9.

39. Rao SD, Matkovic V, Duncan H. Transiliac bone biopsy. Complications and diagnostic value. Henry Ford Hosp Med J 1980;28:112-5.

40. Hernandez JD, Wesseling K, Pereira R, Gales B, Harrison R, Salusky IB. Technical approach to iliac crest biopsy. Clin J Am Soc Nephrol 2008;3:S164-9. 